\title{
Research on Legal Issues of Confirmation of Shareholder Qualification of Limited Liability Companies
}

\author{
Bo Han \\ College of Civil and Commercial Law \\ Shandong University of Political Science and Law \\ Ji'nan, China
}

\begin{abstract}
After the revision of the Company Law in 2013, limited liability companies gradually became the focus of trial practice in judicial practice. Unlike the administrative rules and regulations promulgated by the CSRC, the limited liability company has become the focus of the Supreme People's Court regulation. The conclusions can be drawn from the guidance cases published by the Supreme People's Court. In the number of guidance cases published by the Supreme People's Court, the identification of the company's shareholder qualifications is undoubtedly the focus of attention, but it must be clearly understood that the Supreme People's Court still has some misunderstandings on the issue of confirmation of shareholder qualifications. However, there are still different views on some issues and some inconsistencies in the refereeing cases and common cases in the refereeing. Therefore, it is necessary to carry out in-depth research on this issue, in order to better clearly grasp the referee scale and improve the judicial credibility in the trial practice.
\end{abstract}

Keywords-limited liability company; shareholder qualification; confirmation

\section{INTRODUCTION}

In 2013, China's Company Law was substantially revised, the requirements of the statutory capital system were abolished, the requirements for capital verification were abolished, and a large reform was carried out in the capital system. Most of the academic circles focused on the reform of the company's capital system. On the other hand, there is no in-depth study of other systems of the company law, but according to the system theory, any system modification in the system will have a relatively large impact on other systems. The revision of the company's capital system will inevitably have a greater impact on the recognition of shareholders' qualifications. In particular, after the payment system is changed to the subscription system, the impact will become even greater. At the same time, with the further liberalization of capital controls, the equity trading market has become more active, and the legal problems have also increased. The Supreme People's Court has also published several batches of guiding cases, and the identification of shareholder qualifications in the context of capital contribution is implicit. In the context of capital contribution, the identification of shareholder qualifications has been made in more detailed terms, but it has been seen that many of the guidance cases of the Supreme People's Court are often not supported by a profound theoretical background, often lacking a strict legal basis, because it is necessary for shareholders of limited liability companies to further make study on qualification confirmation issues

\section{THE BASIC THEORY OF THE CONFIRMATION OF} SHAREHOLDERS' QUALIFICATIONS OF LIMITED LIABILITY COMPANIES

The shareholder qualification of a limited liability company mainly refers to what kind of person can become a shareholder of a limited liability company. The French Civil Code has made such a description of the qualifications of shareholders. "The company recognizes that it enjoys half of the subscribed or acquired shares and has shareholder qualifications." This issue is very important in the Company Law. The qualification confirmation problem mainly has the following functions and meanings.

\section{A. Qualification Confirmation Is the Basis for Shareholders to Enjoy Shareholder Rights}

As is known to all, shareholders are entitled to shareholder rights, so how to determine the ownership of shareholder rights? It is necessary to confirm the right, and only if the right is confirmed, can people stop the dispute and determine who owns the equity. At the same time, only when the identity of the shareholders is clarified can it be able to determine who has the right to dispose of the shares, such as transferring or pledging the shares.

\section{B. Qualification Confirmation Is a Must for Corporate Governance Structure}

The company is a legal person. According to Kirk's organism, the legal person should have its own independent organization. Therefore, the company's organization plays a decisive role in the formation of the company's legal personality. As a real entity, the company should have its own independence. The independence means that the company is not the same as the ordinary natural person and 
does not have the physiological mechanism of its own meaning. So how do you form your own meaning? This mainly depends on the company's resolution, and the nature of the company's resolution has different views in theory. Some think it is legal behavior, and some think it is meaning realization. There are also different classifications in the middle of legal behavior, some are considered to be legal acts of both parties, and some are considered multi-method behaviors. However, no matter what the views have some consensus, the effective establishment of the resolution must be based on the premise that the participants have the qualifications of the shareholders, and the establishment of the resolution also requires some procedural requirements, such as advance notice, if the shareholder qualifications are not confirmed, then the notification is not possible.

\section{Shareholder Qualification Is a Pre-qualification for Certain Judicial Litigation Cases}

For example, if you want to file a subrogation lawsuit, you must have a shareholder qualification. Otherwise, you can't file a subrogation lawsuit. The same is true for the right to know suit. When you file a lawsuit, you must prove the shareholder status. Therefore, an important aspect of the people's court review in these cases is whether the plaintiff has shareholder qualifications.

\section{Shareholder Qualifications Are Also the Basis for Certain Legal Responsibilities}

Shareholder qualifications not only represent rights, but also represent some obligations, such as the capital contribution obligations of shareholders, the shareholders' obligations to creditors in the case of capital contribution and withdrawal of capital contributions. Only when the shareholders' qualifications are determined can the subject of these obligations be clarified.

\section{CONFIRMATION OF SHAREHOLDERS' QUALIFICATIONS OF LIMITED LIABILITY COMPANY IN TIMES OF ORIGINAL ACQUISITION}

There are two main types of shareholder qualifications, one is the original acquisition, and the other is the acquisition. The original acquisition mainly includes obtaining the shareholder qualification through capital contribution when the company is established, and participating in the capital increase to obtain the shareholder qualification when the company increases capital, and obtaining the equity in good faith. After obtaining the acquisition of equity from the old shareholders through the transfer mainly during the company's survival process, it also includes obtaining equity through inheritance and enforcement. The confirmation of shareholder qualification in the original acquisition situation mainly has the following problems.

\section{A. The Issue of Shareholder Qualifications at the Time of Establishment of the Company}

The issue of shareholder qualification in the establishment stage is relatively simple, because limited liability companies are established by means of initiation and establishment. The initial shareholders are generally sponsors. Therefore, there is usually a sponsor agreement, and they are generally established during the establishment process.

\section{B. The Issue of Shareholder Qualifications When the Company Increases Its Capital}

The recognition of shareholder qualifications during the company's capital increase is often complicated. The reason is that the company has already been established when the company increases its capital. Therefore, the newly joined shareholders are not sponsors, and no sponsor agreement is signed. The capital increase agreement is often signed, and the signing party of the capital increase agreement is signed. In practice, there are different practices, some are signed with the original controlling shareholder, some are signed with the company, and the capital increase behavior should be the legal behavior between the newly joined shareholders and the company, and if it is signed by the new shareholder and the capital increase shareholders, there will be some problems. In this case, it can be seen that the court is more cautious in determining the shareholder qualifications at the time of capital increase. The requirement is that there are three conditions at the same time. The first one is that the shareholder must have the meaning of capital contribution. If not, it is only the use of funds. If you agree, you can't make it up. The second requires shareholders to exercise their equity. This not only requires shareholders to exercise the right to self-interest of dividends, but also requires shareholders to exercise voting rights and other rights, and the third requires shareholders not to be able to withdraw their capital at will. At the same time, the qualification recognition of shareholders at the time of capital increase also involves the delivery of capital contribution. Especially in the case of currency contribution, the fact that the currency is credited to that account is also a situation in which disputes are highly prone to occur. If the company account is hit, the situation is relatively simple. If you break into the personal account of the controlling shareholder, the situation will be more complicated. On the other hand, it depends on whether the newly added shareholders have external markers, and external signs are also important in practice. Of course, there are different opinions on how to determine the external markers in the capital increase. Some claims are the shareholder register, some are the capital contribution certificates, some are the company's articles of association, and some are the registration of the company registration authority. The author thinks the register of shareholders is an appropriate external marker. Because the shareholder register is a document that must be prepared in a limited company, it can be sufficiently confrontational. At the same time, according to Article 32 of the Company Law, the shareholders recorded in the register of shareholders can claim rights from the company according to the register of shareholders. On the contrary, the validity of the capital contribution certificate is lacking, because the capital contribution certificate is only a kind of agreement between the shareholders and the company. Although the capital contribution certificate is stamped by the company, the company does not have the obligation to have a receipt. 
Therefore, its nature is similar to the contract and there is no publicity. Therefore, it is difficult to become a means of publicity. The effectiveness of the company's articles of association is relatively high, but according to the provisions of the company law, the amendment of the charter resulting from the transfer of shareholders does not require the opening of a shareholders meeting, and therefore is not a valid means of publicity. The registration of the industrial and commercial authorities should be the highest effective registration, and it can counter the external third party. However, according to Article 32 of the Company Law, industrial and commercial registration should only be effective against confrontation and there is no transfer of rights. However, there are still some problems in the current law of the company's shareholder register. In particular, there are still some problems compared with the real estate registration on the civil law, mainly because the level of effectiveness is still relatively low, and there is no strict formal requirement compared with the real estate registration. The law only stipulates the general content of the register of shareholders, but does not specify the specific form. There are still some problems in the capital increase. If there is no problem with both capital contribution and external markers, and if there is only one item, there will be some problems. In practice, it is more difficult to identify. For example, although it is funded, it does not. External markers, such as no capital contribution certificate, no record of the shareholder register, no amendments to the charter. Therefore, people must consider other aspects, such as whether to participate in the company's dividends and whether to participate in the meeting of the shareholders meeting. There are also other questions, for example, how to judge if there is an inconsistency between the external markers. In the case of "Huang Weizhong v. Chen Qiangqing and other shareholder qualification confirmation cases", the Shanghai No. 2 Intermediate People's Court held that "the company's shareholder's shares were not diluted by the company's effective shareholder's resolution. If there is a legitimate interest of the shareholder, even if the investment has been registered by the industrial and commercial administration, it should be deemed invalid, and the original shareholding ratio of the company should remain unchanged."

\section{The Equity Is Obtained in Good Faith}

The acquisition of equity in good faith is also a kind of original acquisition. It mainly refers to the unauthorized disciplinary of the equity to dispose of the equity of others. If the subjective state of the third party is in good faith, the act of acquiring the equity may be obtained. The acquisition of goodwill of equity is more complicated, especially for the issue of the validity of the right to dispose of equity. Some believe that it can be determined as an effective act with reference to the provisions of the judicial interpretation of the applicable sale contract. Some people think that it is an act of undetermined effectiveness, and at the same time, whether the goodwill acquisition of equity is divided into preconditions with no rights, there are also different views. Some scholars believe that the acquisition of good faith is closely related to the disposition of power, and some scholars believe that the acquisition of good faith does not necessarily presuppose the powerlessness. In several of the Supreme Court's guidance cases, it can be seen that many good faith acquisitions are associated with forged signatures, and forged signatures do not fully comply with the true definition of unauthorized disposition; in the case of forgery of signatures, the actor who performs the punishment is not in his own name but in the name of others, which is a disciplinary act. Therefore, it is believed that the good faith acquisition of equity is not predicated on the unauthorized. In addition, should the conditions for the good faith acquisition of equity be based on the applicable property rights? This issue also has different views. Some scholars believe that equity and property rights are absolute rights, so they can refer to the application. Some scholars believe that equity is different in nature from property rights and can't be fully applied. Equity and property rights do have their own particularity. It is a compound right. It is both the property of the human right and the property of the property right. It is indeed doubtful whether it can be completely consistent with the real right when it is acquired in good faith. For example, how to judge the goodwill of a third person is that it is relatively easy for a third person to be a natural person to judge in the real right, but the equity is different, and many of them are companies. Then how to determine the subjective state of the company becomes more difficult to determine. In judicial practice, it is often the subjective state of the legal representative of the company. In addition, there are some disputes about how to determine the external publicity means in the acquisition of goodwill. Some opinions claim that the registration of industrial and commercial organizations, and some claims are changes in the register of shareholders. In this respect, it is similar to the goodwill of special motor vehicles. The author thinks that it is more appropriate to determine the external publicity means as industrial and commercial registration; because compared with the register of shareholders, the industrial and commercial registration has the characteristics of against a bona fide third party and can be used as a means of publicity.

\section{THE RECOGNITION OF SHAREHOLDER QUALIFICATIONS UPON ACQUISITION}

The recognition of shareholder qualifications upon acquisition is relatively more complicated than the original acquisition, because it involves the transferor's relationship with the transferor and the sign of equity changes. At the same time, the issue of identity inheritance is also involved in inheritance. In the case of enforcement, it involves the issue of the change of rights caused by legal documents. In the case of divorce, it also involves the issue of whether the spouse can obtain the qualifications of the shareholders. These problems have caused great problems in the confirmation of the qualifications of the shareholders and caused a lot of controversy.

\section{A. Confirmation of Shareholder Qualification at the Time of Equity Transfer}

If there is a transferor and a transferee at the time of equity transfer, then when can the transferee be recognized 
as a shareholder qualification? This issue also has different views. Some claim that the equity transfer contract will take effect. Some claims require changes in the register of shareholders, some believe that changes to the charter are required, and some believe that business registration is required. This problem seems to be more important in the case of multiple turnovers. In the case of multiple turnovers, it is more important to determine who the true successor of equity is. In the context of more than one car and more than one room, the Supreme Court has set priorities in the judicial interpretation of the sale contract. If there is a multi-turn in the equity transfer, what should be done? Some assignee companies issued certificates of capital contribution, some assignees changed the register of shareholders, some assignees appeared in the charter, and some did business registration. It is believed that it is still necessary to give priority to the validity of the industrial and commercial registration, because the industrial and commercial registration is public and can be used against third parties. The second overall pick should be the register of shareholders, because the shareholder register is a standing document of the company and has strong publicity. The third order should be the company's articles of association. The company's articles of association are self-governing norms and have high effectiveness. The fourth order should be the capital contribution certificate, which is the weakest.

\section{B. Confirmation of Shareholder Qualification During Equity Inheritance}

In the case of equity inheritance, the issue of confirmation of shareholder qualification is also involved, and the successor of the shareholder can automatically obtain shareholder qualification. The provisions of the company law on this issue are arbitrary specifications, that is, the successor of the company's shareholders can automatically obtain the shareholder qualification, except as otherwise provided in the articles of association. In practice, it is mainly unclear about where the boundaries of autonomy of the charter are. For example, some companies stipulate that shareholder qualifications can't be inherited. If a person dies, the company will buy back shares. Then, can the successor be qualified in this case? This actually involves the boundary issue of the company's charter autonomy norms. This issue should be considered in conjunction with the person and sex of a limited liability company. Since the number of limited liability companies is generally small, it has a relatively strong human and sexual nature, so it is possible to make such restrictions. Of course, some people have different views on the issue of inheritance of shareholder qualifications. The main controversy is that the modern inheritance law considers inheritance to be mainly property inheritance, but does not stipulate identity inheritance. The shareholder qualification is not only the property of the nature but also the right of the person. It is a compound right. We believe that identity inheritance and shareholder qualification inheritance are different, because the shareholder qualification is mainly caused by the capital contribution behavior, so it is different from the positions of directors and senior executives. Directors and senior executives are elected, and of course, they can't be inherited.

\section{Confirmation of Equity Qualifications When Equity Is Enforced}

Enforcement of equity is also an important source for shareholders to obtain. Unlike ordinary external transfer, there is no consent procedure in equity enforcement, but other shareholders still have the right of first refusal. At the same time, there is still a problem of when the shareholder qualifications are transferred when the enforcement is enforced. The change of property rights caused by legal documents in the property law is considered to be a change of property rights caused by non-legal acts. Generally, the legal document takes effect as the effective time of the change of property rights. Then, can the shareholder qualification refer to this rule? This involves the question of how to define the scope of legal instruments. Can all legal instruments lead to changes in property rights? It is believed that only legal documents involving the formation of a lawsuit can lead to changes in property rights, because only the formation of a lawsuit will lead to changes in the legal relationship, and the payment of the lawsuit will not lead to changes in the legal relationship. So does the execution of the program lead to changes in property rights? It is believed that the implementation of the procedure can not directly affect the effect of property rights changes, whether it is the auction process or the debt repayment model, in order to change the property rights and publicity means, the movable property needs to be delivered, and the real estate needs to be transferred. Therefore, it is believed that the enforcement of equity also requires publicity, and changes in the register of shareholders should be required to obtain shareholder qualifications.

\section{Confirmation of Shareholder Qualifications When Shareholders Divorce}

How to determine the shareholder qualification when the shareholders divorce is also a relatively important issue. If the equity is obtained before marriage, it is relatively simple, because this is the personal property of the spouse. Of course, this also involves the issue of equity appreciation after marriage. According to the judicial interpretation of the marriage law, one party invests in the pre-marriage personal property. The value-added part belongs to the joint property of the husband and wife. However, it is more doubtful that if the equity belongs to the joint property of the husband and wife, but it is registered separately under the name of one person, then the situation will be special. Although the equity belongs to the joint property of the husband and wife, if the party not registered on the shareholder register wants to become a shareholder, the party must pass the consent of more than half of the other shareholders.

\section{CONFIRMATION OF THE SHAREHOLDERS' QUALIFICATIONS OF THE LIMITED LIABILITY COMPANY}

The issue of confirming the qualifications of shareholders of limited liability companies in the case of capital contribution has always been a controversial issue in practice. Some scholars pointed out that with the revision of the 13year company law in China, the reform of the registered capital system will make this problem simple. But in fact, 
although the reform of the registered capital system has solved some old problems, it will still bring some new problems. For example, if the registered capital is too large, and the paid-in registered capital is too small, the actual payment period is too long. Therefore, further research is still necessary. Capital contribution refers to the behavior of shareholders who fail to fulfill their capital contribution obligations as stipulated in the charter, including the failure to fulfill the capital contribution obligation (the motor vehicle is not delivered, the real estate has not been transferred), the false capital contribution in the case of nonmonetary contribution, and the withdrawal of capital after the establishment of the company. It is always a controversial issue whether the shareholders who have contributed capital in the case of capital contribution have shareholder qualifications. Some scholars have argued that shareholders who donate money only need to bear their corresponding responsibilities, but have no influence on shareholder qualifications. Some scholars have argued that the capital contribution will not affect the qualifications of shareholders, but the withdrawal of capital and false capital contribution will affect the qualifications of shareholders. It is believed that the key question here is how to determine the consequences of the capital contribution, namely whether the capital contribution may lead to the elimination of shareholder qualifications. It is believed that according to the judicial interpretation of the Supreme Court, it is illegal to make capital contributions and withdraw funds. It is legally responsible, including the responsibility of delisting or the elimination of shareholder qualifications, but the delisting procedure in the limited company people are paying attention to is very strict; first of all, it must be completely unpaid or all of the capital is withdrawn, that is, the level of funding is relatively high, and the procuring procedure needs to be performed. It is necessary to lodge a reminder to the shareholders who have contributed, and the procedural must convene a shareholders meeting. The voting is carried out, and at the same time, the external responsibility of the shareholders after the de-listing process is not extinguished immediately, but after the completion of the capital reduction procedure or the transfer of funds to a third party. Controversial in practice is whether false capital contribution will lead to the elimination of shareholder qualifications, such as the use of assets that do not have the right to dispose of funds or the use of funds that are overvalued for nonmonetary contributions. In the absence of discretionary funding, people need to consider whether the company constitutes a good faith acquisition. If it constitutes a good faith acquisition, then shareholders should be able to obtain shareholder qualifications. In the case of excessive evaluation, it is believed that people must combine different periods of China and take into consideration of the status of registered capital legislation. After 2013, the registered capital of China has been reformed, and the company no longer sets a minimum registered capital limit. Therefore, the capital contribution will not lead to the failure of the establishment of the company, and thus will not lead to the elimination of shareholder qualifications. However, it was different before 2013. At that time, the limited company had the minimum registered capital limit. Therefore, if the false capital contribution of the shareholders causes the company's registered capital to be lower than the minimum limit, then the establishment of the company will cause problems, so the qualification of the shareholders will be problematic. Of course, the 93 Company Law and the 06 Company Law also has the problem of whether the registered capital is paid in full. 93 Company Law requires the registered capital to be paid in full, and the 06 Company Law allows the company shareholders to pay in installments. This involves a deeper question, that is, whether the registered capital in the establishment of the company is actually paid or subscribed. This issue has been constantly changing since 1993, and its essence is what the credit basis of the company is. There is a different understanding. Early scholars generally believed that the company's credit base was the company's registered capital, so the Company Law emphasized the need to pay, while recent scholars believe that the company's credit base is not in the registered capital, but in the company's assets. Therefore, the company's shareholders do not need to pay the registered capital when the company is established, but only need to assume a guarantee responsibility.

\section{CONFIRMATION OF SHAREHOLDERS' QUALIFICATIONS OF LIMITED LIABILITY COMPANY WHEN ANONYMOUS INVESTMENT IS MADE}

The identification of shareholders' qualifications of limited liability companies under the name of anonymous investment is also a major practical issue, especially the issue of holding equity. The anonymous investment means that the shareholders recorded on the shareholder's register are only nominal shareholders, and the nominal shareholders' contributions are derived from the actual funders. Some scholars advocate that based on actual capital contribution, the actual investor has the qualification of shareholders, and some scholars advocate that the nominal investor has the shareholder qualification based on the register of shareholders and the charter. In particular, both parties generally have an equity holding agreement, and there are often equity ownership and shareholder qualifications in the equity holding agreement. Therefore, it also involves whether the contract can stipulate the ownership of the shareholders. This is similar to the material debt repayment agreement in the property law. It only has the effect of creditor's rights and can't produce the effect of property rights changes. By the same token, the equity holding agreement is only valid for claims and can't produce the effect of changes in shareholder qualifications. Therefore, it is believed that a hidden shareholder who wants to obtain shareholder qualifications must go through legal procedures and obtain the consent of more than half of the shareholders of the company. However, nominal shareholders and ordinary shareholders still have some differences in some jurisdictions. Some scholars believe that the shareholdings enjoyed by nominal shareholders are incomplete, for example, they can't be arbitrarily disposed of. However, the author disagrees with this view. The author believes that the shareholdings enjoyed by the nominal shareholders are complete. The provisions of the Judicial Interpretation III of the Company Law are problematic because the equity holding agreement is only a contract, and the contract is 
relative, only being able to constrain the opposite party of the contract can't restrain the third person, so there is no problem in the goodwill of equity. Therefore, it is not necessary to consider the subjective status of the third party. In the judicial interpretation of the company law, the Supreme Court's view is that the nominal shareholder's disposition of the equity is not entitled to disposition, and whether the third party obtains the equity depends on the third party. Under the subjective state, such a rule is unreasonable.

\section{CONFIRMATION OF SHAREHOLDERS' QUALIFICATIONS OF LIMITED LIABILITY COMPANY UPON IMPERSONATION}

Imposing capital contribution refers to the situation in which the actual shareholder contributes in the name of the nominal shareholder without the consent of the nominal shareholder. The difference between impersonation and anonymous funding is whether there is an agreement between the nominal and actual shareholders. The identification of shareholders' qualifications against the background of impersonation is also a complicated issue. The third interpretation of the judicial interpretation of the Company Law is that the actual investor has the shareholder qualification, and the nominal investor does not have the shareholder qualification. However, there is a problem worth considering here. The actual investor does not appear in the register of shareholders, the charter, and the industrial and commercial registration. Can it be considered as a shareholder? If it is directly recognized as a shareholder, is it a violation of the principle of commercial appearance? It is believed that there should be no doubt that the nominal investor does not have the shareholder qualification, because the meaning of the lack of capital contribution is expressed, but the actual investor's shareholder qualification is actually questionable. For example, in the case of impersonation, whether the actual investor can participate in the general meeting of shareholders can enjoy the dividend of the company. If the actual investor and the spouse are divorced, can the spouse ask for the split of the equity? And if the imposter does constitute the capital contribution, who should be responsible for companies and creditors becomes a matter of controversy. Article 28 of the Judicial Interpretation of the Company Law is only a general statement that there should be an imposter funder to take responsibility, but there is no clear nature of the responsibility, so the responsibility of the imposter investor should be clarified.

\section{CONCLUSION}

The issue of the confirmation of shareholders' qualifications in limited liability companies is a relatively controversial issue in judicial practice. In particular, the Supreme People's Court has made detailed regulations in the judicial interpretation of Company Law, but it still can't respond correctly to some theoretical issues. Therefore, it is necessary to carry out in-depth combing from the theoretical level, in order to better handle such disputes in judicial practice.

\section{REFERENCES}

[1] Fu Yulin. Research on the Public Notice System of Stock Rights Changes of the Company Limited by the Registration of Shareholders' Register, Beijing: Law Press, 2010.

[2] Luo Peixin. Contract Interpretation of Company Law, Beijing: Peking University Press, 2004.

[3] Peng Chunlian. Research on the Relief Mechanism of Shareholders Rights - from the Perspective of Judicial Relief, Beijing: Law Press, 2010.

[4] Wang Hongyi. Sociological Analysis of Corporate Law and Structural Law: Research on Corporate Legislation, Beijing: Peking University Press, 2001.

[5] Wu Yue. The Centennial Controversy of the Private Limited and the Reconstruction of the Century - Compared with China and the European Union, Beijing: Law Press, 2005.

[6] Zhang Hanjun. Principles and Practice of Corporate Law in Hong Kong, Beijing: Science and Technology Popularization Press, 1994.

[7] Feng Xingjun. Acquisition and Loss of Limited Liability of Shareholders, Journal of Wuhan University (Philosophy and Social Sciences Edition), 2008, first issue.

[8] Zhicun Zhimei. On the Relationship Between the Company's Capital and Capital Contribution, Foreign Law Translation Review, No. 2, 1994.

[9] Jiang Daxing. "The Return Path of Public Information? - Utopia of the Register of Shareholders and Business Licenses, Hebei Law, No. $10,2005$.

[10] Lou Jianbo. On the Inheritance of Shareholders and the Inheritance of Shareholders' Qualifications of the Shareholders of the Company, Contemporary Law, No. 5, 2007. 